\title{
POTENTIAL OF MANGROVE SEEDLINGS FOR UTILIZATION IN THE MAINTENANCE OF ENVIRONMENTAL QUALITY WITHIN SILVOFISHERY PONDS
}

\author{
ENDAH DWI HASTUTI ${ }^{*}$ and RINI BUDIHASTUTI \\ Faallyof SaienceandMathematics DiponegroUnivesity, \\ Semarang50275, Indonesia
}

Received 10 January 2016/ Accepted 24 June 2016

\begin{abstract}
ABST RACT
Silvofishery system has been applied to aquaculture activities and it has been developed in the coastal area of Semarang City, Indonesia. However, information on the initial development of silvofishery ponds concerning the functionality of mangrove seedlings on environmental quality of fishponds had not been studied. This experiment aimed to determine the environmental conditions of silvofishery ponds and to analyze the effect of seedling stands of mangrove on environmental quality control. The presence of mangrove seedlings caused the decrease of temperature and the increase of salinity. ANOVA showed that mangrove species significantly affected water salinity, while canal width and mangrove species significantly affected turbidity and $\mathrm{pH}$. Regression analysis showed that the height of Rhizqphrammonata had partially significant effect on Total Suspended Solids (TSS), O rganic Matter (OM), as well as Nitrogen $(\mathrm{N})$ and Phosphorus $(\mathrm{P})$ concentrations. Diameter of R. mmanata affected temperature. The height and diameter of Avicaniamminaaffected D issolved O xygen (D O). Mixed populations of A. maimaand R mmonata had an effect on water turbidity, while population of only A. maina had a partial effect on water salinity. R. mmonata seedlings had dominant effect on the environmental quality. Mangrove seedlings can be used as environmental quality control within silvofishery ponds to maintain optimal conditions for fish growth. The application of silvofishery in early stage of mangrove seedlings should consider the more abundant plantation of $\mathrm{R}$. mircata compared to A. manina
\end{abstract}

Keywords: Canal width, environmental quality, seedling, silvofishery, species composition

\section{INTRODUCTION}

The unsustainable utilization pattern of coastal areas has caused environmental damage (Primyastanto \&al. 2010), and the most affected sectors by the damage is pond aquaculture activities (Pramudyanto 2014). However, the development of beach and upland areas also has contributed to degradation of environmental quality (Vatria 2010).

O ne of the applied methods to maintain the sustainability of pond culture activity is the silvofishery culture system (Surtida 2000). Silvofishery is an aquaculture system which combines mangrove trees with shrimp/fish ponds. The integration of mangrove stands

\footnotetext{
*Corresponding author: endah_pdil@yahoo.com
}

within silvofishery ponds are expected to improve the environmental quality and increase the carrying capacity of the system (Wibowo \& Handayani 2006). According to Suwarto \& al. (2015), the existence of mangrove vegetation in ponds will improve primary productivity as well as assimilation capacity of pond effluents.

Several silvofishery pond models have been applied in many regions including komplangan empang parit and enhanced empang parit (Bengen 2002). All three models integrate the mangrove community into the pond area (inlet/ outlet). The function of mangroves within the ecosystem is to provide nutrients through nutrient trapping and litter production and to absorb pollutants. Mangrove should grow in both the inlet area as pollutant absorbers and in the outlet area to neutralize the pond effluent. However, the 
application of a mangrove community in both inlet and outlet of silvofishery systems had not been developed.

The potential utilization of mangrove in environmental quality control within aquaculture ponds through the application of silvofishery is expected to decrease the risk of aquaculture activity as well as to improve pond productivity (Lewis III \& Gilmore 2007). However, the optimal function of mangrove stands to the environment may not be achieved until trees are mature. In the meanwhile, the growth of mangrove from seedling stage to tree requires a longperiod of time.

The influences of mangrove seedlings planted in seedling plantations on the quality of pond environment have received very little attention. Although the effect of mangrove seedlings on the control of environmental quality is not highly significant, the existence of mangrove seedlings should provide certain effects on water circulation pattern as well as absorption of nutrients or pollutants. Thus, the role of mangrove seedlings in silvofishery ponds, especially in early plantations needs to be studied.

Semarang City is a region in Indonesia that has experienced ecological disturbance from unsustainable development activities in the past as well as regional development leading to environmental stress increase in coastal areas. Pond culture occupying silvofishery system had been applied in Semarang City, but it is not optimized to support the productivity of aquaculture. This experiment aimed to determine the environmental conditions of silvofishery ponds and to analyze the effect of seedling stands of mangrove on environmental quality control.

\section{MATERIALS AND METHODS}

The experiment was conducted in Mangunharjo Village, Tugu District, Semarang City, Central Java Province, Indonesia from March to September 2015 by planting mangrove seedlings in silvofishery ponds at the inlet and outlet canals. Materials used were height and diameter of seedling stands as well as water and sediment quality parameters representing environmental quality i.e. temperature, turbidity, salinity, pH, Dissolved Oxygen (DO), Total Suspended Solids (TSS), O rganic Matter (O M), as well as Nitrogen (N) and Phosphorus (P) concentrations.

Experimental design involved treatments of canal widths and mangrove compositions. Canal widths were 1,2 and $3 \mathrm{~m}$. Canal length was $5 \mathrm{~m}$ for all treatments. The size of culture ponds were $5 \times 5 \mathrm{~m}^{2}$ with $1.5 \mathrm{~m}$ depth. The canals were build on both sides of the ponds as inlet and outlet canals. Composition of the mangrove seedlings were: 1. Avicenia maina (A); 2. Rhizqhora mirconata(R); or 3. amixture of the two mangrove species (M). The plantation space among seedling stands was $1 \times 1 \mathrm{~m}^{2}$, so the number of mangrove stands for each treatments were 5 stands ( $1 \mathrm{~m}$ L1); 10 stands (2 m - L2) and 15 stands (3m- L3). The experiment was conducted with 3 replications. The design of the experiment is shown in Table 1 and the diagram of the experiment is shown in Figure 1.

Data collections and observations were conducted every 3 months i.e. in March, June and September 2015. Data collected were: 1. water quality parameters i.e. temperature, turbidity, salinity, pH, DO (Dissolved Oxygen) and TSS

Table 1 Design of the experiment

\begin{tabular}{lccc}
\hline \multicolumn{1}{c}{$\begin{array}{c}\text { Seedling } \\
\text { composition }\end{array}$} & \multicolumn{3}{c}{ Canal width } \\
\cline { 2 - 4 } & $1 \mathrm{~m}$ & $2 \mathrm{~m}$ & $3 \mathrm{~m}$ \\
\hline Avicemia marina & L1-A & L2-A & L3-A \\
Rhizquhra mrranata & L1-R & L2-R & L3-R \\
Mixture of both mangrove & L1-M & L2-M & L3-M \\
species & & & \\
\hline
\end{tabular}




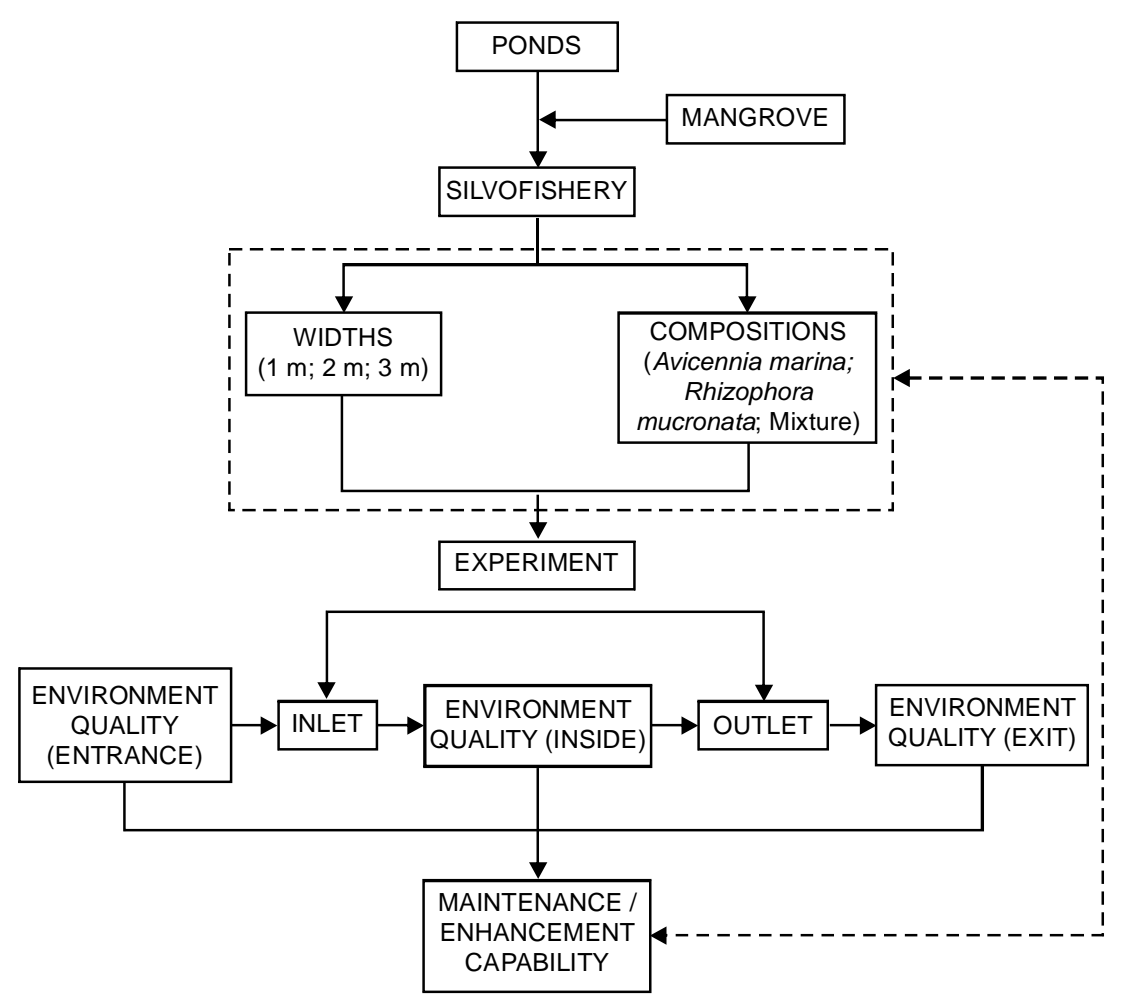

Figure 1 Diagram of the experiment

(Total Suspended Solids); and 2. sediment quality parameters i.e. OM (O rganic Matter), as well as $\mathrm{N}$ (Nitrogen) and $\mathrm{P}$ (Phosphorus) concentrations. Data processing was conducted to determine the impact caused by mangrove stands on the environmental quality represented by water and sediment quality parameters value changes in the inlet and outlet canals. Factorial ANOVA and multiple regression analysis were used to analyze the collected data. Factorial ANOVA was conducted to analyze the impact of treatments involving the combination of canal widths and mangrove composition on water and sediment quality parameters. Multiple regression analysis was conducted to analyze the influence of seedling variations (including the combination of population, measurements and species compositions) on the value changes of environmental quality parameters. Multiple regressions analysis involved: 1 . independent variables for respective mangrove compositions i.e. seedling height, seedling diameter and population of mangrove seedling particularly for A. manina and R. murronata, and 2. dependent variables i.e. changes of temperature, turbidity, salinity, $\mathrm{pH}, \mathrm{DO}, \mathrm{TSS}, \mathrm{OM}, \mathrm{N}$ and $\mathrm{P}$ concentrations.

\section{RESULTS AND DISCUSSION}

D ata collected showed changes in water and sediment quality parameters in the silvofishery ponds (Table 2).

Water temperature consistently decreased from the first to the third observations, while salinity consistently increased. Other parameters did not show any specific pattern of changes.

The observed water and sediment quality parameters within the inlet and outlet canals of silvofishery pond showed the decrease and increase of parameters values, before and after passing the canal with mangrove stands. The changes of water and sediment quality parameters value within the canals varied among treatments.

This experiment showed the value changes on water and sediment quality parameters within the pond canals i.e. temperature changes ranged from $(-) 5.5$ to $(+) 6.4{ }^{\circ} \mathrm{C}$; turbidity ranged from $(-) 710$ to $(+) 769$ NTU; salinity changes ranged from $(-) 6.3$ to $(+) 6.1 \%$; $\mathrm{pH}$ ranged from $(-) 6.1$ to (+)6.2; D O ranged from $(-) 4.1$ to $(+) 4.5 \mathrm{mg} / \mathrm{L}$; TSS ranged from (-)343.2 to $(+) 509.4 \mathrm{mg} / \mathrm{L} ; \mathrm{O}$ M ranged from $(-) 2.7$ to $(+) 2.5 \%$; $\mathrm{N}$ concentration ranged from $(-) 0.7$ to $(+) 0.7 \%$; and $\mathrm{P}$ concentration ranged from (-)50.9 to $(+) 52.8$ 
Table 2 Changes in water and sediment quality parameters value observed during the experiment

\begin{tabular}{llccc}
\hline No. & Parameter & Observation & Observation & Observation \\
\hline 1. & Temperature $\left({ }^{\circ} \mathrm{C}\right)$ & 34.2 & II & III \\
2. & Turbidity (NTU) & 379.7 & 31.4 & 30.6 \\
3. & Salinity (\%) & 22.0 & 313.0 & 353.7 \\
4. & pH & 7.49 & 31.0 & 39.8 \\
5. & D O (mg/ L) & 6.56 & 9.26 & 8.11 \\
6. & TSS (mg/ L) & 411.37 & 6.99 & 5.72 \\
7. & O M (\%) & 1.64 & 492.04 & 218.00 \\
8. & N (\%) & 0.53 & 1.74 & 1.62 \\
9. & P (ppm) & 33.86 & 0.55 & 0.55 \\
\hline
\end{tabular}

ppm. The changes indicated that water and sediment quality changed during the 3 observation periods. The range of parameter values varied among observation periods.

Height and diameter measurements on mangrove seedling stands also showed variations among the 3 observation periods. Height of A. maninastand ranged from 41 to $106 \mathrm{~cm}$; from 43 to $101 \mathrm{~cm}$; and from 39 to $106 \mathrm{~cm}$ with stand diameter range of $0.20-0.89 \mathrm{~cm} ; 0.32-0.88 \mathrm{~cm}$; and $0.15-1.94 \mathrm{~cm}$ for the first, second and third observations, respectively. Height of $\mathrm{R}$ murronata stand ranged from 28 to $60 \mathrm{~cm}$; from 24 to $76 \mathrm{~cm}$; and from 38 to $78 \mathrm{~cm}$ with stand diameter range of $0.22-1.90 \mathrm{~cm} ; 0.30-1.32 \mathrm{~cm}$; and $0.55-2.36$ $\mathrm{cm}$ for the first, second and third observations, respectively. Decreased seedling height and diameter of each mangrove species was caused by the mortality of seedlings, hence seedlings replacements were conducted several times.

Data analysis with ANOVA to measure the effect of canal width and mangrove compositions (treatments) on water and sediment quality parameters showed that several parameters were significantly affected by the treatments, such as mangrove composition affected salinity, canal width and mangrove composition affected turbidity and $\mathrm{pH}$. Significant effect on water salinity was achieved from silvofishery pond canals with A. manina and R moronata. While significant effect on water turbidity was achieved from different canal widths and from different mangrove seedling species. Significant effect on $\mathrm{pH}$ was achieved from combination of canal width and mangrove seedling species.
Multiple regression analysis to determine the effect of mangrove stands on the water and sediment quality parameters of silvofishery pond showed that there were significant effects of mangrove stand on several observed parameters (Table 3). Data analysis was conducted partially for each mangrove composition structure as well as water and sediment quality parameters.

Changes in environmental quality parameters within silvofishery pond canals were dominantly influenced by seedlings of R. mucronata(Table 3). Parameters partially influenced by $\mathrm{R}$. murconata stands included changes in TSS concentration, temperature, $\mathrm{OM}$ concentration, N concentration and $\mathrm{P}$ concentration. Seedlings combination of $\mathrm{R}$. mucronata and A. manima influenced water turbidity and D 0 concentration. A. mainaseedlings influenced water salinity.

There was significant effect of $\mathrm{R}$. muranataon TSS concentration. According to Furukawa and Eric (1996), mangrove stands can function as sediment trap. Sediment trapping processes by mangrove stands begins with the slowing down of water current, and this leads to the accumulation of TSS which finally gravitates. Also, sediment trapping is influenced by the tide condition (K athiresan 2003).

Mangrove stand has negative effect on the change of temperature, which means that as the height and diameter of mangrove stands increase, water temperature decreases. According to Hadikusumah (2008), mangrove vegetation is capable of absorbing heat. The photosynthetic capability of mangrove seedling of Rhizophara occurs in the leaves and green stems, hence as the 
Table3 Effect of mangrove stands on changes of water and sediment quality parameters within canals of silvofishery ponds

\begin{tabular}{|c|c|c|c|c|}
\hline No. & $\begin{array}{l}\text { Mangrove } \\
\text { composition }\end{array}$ & $\begin{array}{l}\text { Independent } \\
\text { variable }\end{array}$ & $\begin{array}{l}\text { Dependent } \\
\text { variable }\end{array}$ & Equation \\
\hline 1. & Single & Height of R. micronata(X1) & TSS & $\mathrm{Y}=524.574-8.483(\mathrm{X} 1)$ \\
\hline 2. & Mixed & $\begin{array}{l}\text { Diameter of R. mirconata }(X 1) \text {; } \\
\text { Height of R. murconata }(X 2)\end{array}$ & Temperature & $\mathrm{Y}=-1.091+0.057(\mathrm{X} 1)-1.799(\mathrm{X} 2)$ \\
\hline 3. & Mixed & $\begin{array}{l}\text { Population of A. maina (X1); } \\
\text { Population of R. murcmata (X 2) }\end{array}$ & Turbidity & $Y=-81.627-209.753(X 1)+213.887(X 2)$ \\
\hline 4. & Mixed & Population of A. manina (X1) & Salinity & $Y=-0.432+0.103(X 1)$ \\
\hline 5. & Mixed & $\begin{array}{l}\text { Height of A. maina (X 1); } \\
\text { Diameter of A. maina(X 2); } \\
\text { Height of R. moronata(X3) }\end{array}$ & DO & $\begin{aligned} \mathrm{Y}= & 2.127-0.046(\mathrm{X} 1)+7.410(\mathrm{X} 2)- \\
& 0.050(\mathrm{X} 3)\end{aligned}$ \\
\hline 6. & Mixed & Height of R. mucronata(X1) & $\mathrm{OM}$ & $Y=-1.796+0.050(X 1)$ \\
\hline 7. & Mixed & Height of R. muromata(X1) & $\mathrm{N}$ & $Y=-0.587+0.017(X 1)$ \\
\hline 8. & Mixed & Height of R. muronata(X1) & $\mathrm{P}$ & $Y=-41.303+1.142(X 1)$ \\
\hline 9. & Mixed & Height of R. micronata(X1) & TSS & $Y=-248.833+6.794(X 1)$ \\
\hline
\end{tabular}

stand height and diameter increase the amount of photosynthetic surface increases.

Water turbidity was affected significantly by both A. marina and R. micronata Seedling stands of R. muronata inhibited water flow which increased the concentration of suspended sediment (Yang \& al. 2013). On the contrary, A. maina seedlings had negative effect on the change of water turbidity. According to Weiffen e al. (2006), turbidity could be formed by the increasing population of plankton caused by the accumulation of sediment within the canal. The consumption rate of dissolved nutrient by A. manina probably was the cause of its negative effect on the water turbidity.

Water salinity was affected significantly by A. maina but not by R. mrronata, due to higher evaporation capacity of $\mathrm{A}$. maina than $\mathrm{R}$. muronata. Evapotranspiration within a pond is able to decrease water concentration, while salt is excreted back to the environment through the leaves (Ball $\&$ al. 1988). Hence, the concentration of salt (salinity) increased.

Concentration of D O was negatively affected by height of both A. marima and R. muronata, but was positively affected by diameter of A. maina Stand height of mangroves were suggested to affect the canopy coverage which leads to the decreased light penetration (Kennedy $\notin a$ al. 2002). As the mangrove stand height increases, so does canopy coverage. On the contrary, mangrove seedlings still have chlorophyll in the stem, which means they are able to conduct photosynthesis. Photosynthesis has positive effect on seedling diameter and on the increase of dissolved oxygen concentration.

Nutrient concentration, including $\mathrm{OM}, \mathrm{N}$ and $\mathrm{P}$ within the sediment was significantly affected by the height of $\mathrm{R}$. murronata, but not A. manina Nielsen and Andersen (2003) stated that nutrient accumulation by $\mathrm{R}$. muronata is higher than that of A. maina In the seedling stage, the capability to accumulate nutrients is related to diameter size of mangrove stand which is generally larger for R. murronatathan for A. maninastands. Therefore, R. muromata has higher capacity to inhibit water flow and influence the accumulation rate of sediment which binds more nutrients than A. manina

\section{CONCLUSIONS}

Silvofishery pond canals showed random pattern of environmental quality parameters value changes of turbidity, $\mathrm{pH}, \mathrm{DO}, \mathrm{TSS}, \mathrm{OM}, \mathrm{N}$ and $\mathrm{P}$. Temperature was consistently decreased 
and salinity was consistently increased. Mangrove seedling stands for A. manina or R. mmonata had significant effects on the changes of environmental quality parameters involving various combinations on temperature, turbidity, salinity, D O, TSS, OM, N and P. Species that had most effect on environmental quality parameters value changes was R. muromata

\section{ACKNOWLEDGEMENTS}

The authors acknowledged the Director of Research and Community Services (Ditlitabmas), $G$ eneral D irectorate of Higher Education (D itjen Dikti), Ministry of Education and Culture, G overnment of Indonesiafor financial support.

\section{REFERENCES}

Ball MC, Cowan IR, Farquhar GD. 1988. Maintenance of leaf temperature and the optimisation of carbon gain in relation to water loss in a tropical mangrove forest. Aust J Plant Physiol 15:263-76.

Bengen DG. 2002. Teehnical Guide on the Introduction and Management of MangroveEcosystem Bo gor(ID ): Center of Coastal and MarineResources Studies, IPB.

Furukawa K, Eric W. 1996. Sedimentation in mangrove forest. Mangrove Salt Marshes 1(1):3-10.

Hadikusumah. 2008. Characteristics of physical parameters and chlorophyll-a concentration in Java Sea. J Ilmu Kelautan 13(2):103-12.

Kathiresan K. 2003. How do mangrove forests induce sedimentation? Revista de Biologia Tropical 51:35560.

Kennedy VS, Kleypas JA, Cowan Jr JH, Hare SR. 2002. Coastal andManineEcosystems\& Gldbal ClimateChange US: Pew Center on G lobal Climate Change.
Lewis III RR, Gilmore RG. 2007. Important considerations to achieve successful mangrove forest restoration with optimum fish habitat. Bull Mar Sci 80(3): 823-37.

Nielsen T, Andersen FO. 2003. Phosphorus dynamics during decomposition of mangrove (Rhizophara apialata) leaves in sediments. J Exp Mar Biol Ecol 293:73-88

Pramudyanto B. 2014. Pollution and degradation control in coastal areas. Jurnal Lingkar Widyaiswara 1(4):2140.

Primyastanto M, D ewi RP, Susilo E. 2010. The environment destructive habit by coastal society in Islamic perspective (case study on the fishermen and fish traders in Tambak Beach area, Tambakrejo Village, Wonotirto D istrict, Blitar Region East Java). Jurnal Pembangunan dan Alam Lestari 1(1):1-11.

Surtida MB. 2000. Silvofisheries in Indonesia. SEAFDEC Asian A quacult 22(6):20-1.

Suwarto, Lahjie AM, Ruchaemi A, Simorangkir BDAS, Mulyadi F. 2015. Ecological aspect of non productive fishponds at Mahakam Delta area: revitalization with silvofishery system. GJAR 3(1):27-37.

Vatria B. 2010. Various human activities which lead to coastal ecosystem degradation and its impacts. Journal of Berlian 9(1):47-54.

Weiffen M, Moller B, Mauck B, D ehnhardt G. 2006. Effect of water turbidity on the visual acuity of harbor seals (Phora vitulina). Vision Research [Internet]. 46:1777-83. Available from: doi:10.1016/ j.visres.2005.08.015.

Wibowo K, Handayani T. 2006. Conservation of mangrove forest through silviculture (silvofishery). Jurnal Teknik Lingkungan 7(3):227-33.

Yang J, G ao J, Cheu A, Liu B, Schwendenmann L, Costello MJ. 2013. Vegetation and sediment characteristics in an expanding mangrove forest in New Zealand. Estuarine, Coastal and Shelf Science [Internet]. 134:1-18. Available from: http:// dx.doi.org/ 10.1016/ j.ecss.2013.09.017. 
